Jurnal Konstruksi Hukum | ISSN: XXXX | E-ISSN: XXXX Vol. 1, No. 1, September 2020 Hal. 181-186| Available online at https://www.ejournal.warmadewa.ac.id/index.php/jukonhum DOI: https://doi.org/10.22225/jkh.1.1.2153.181-186

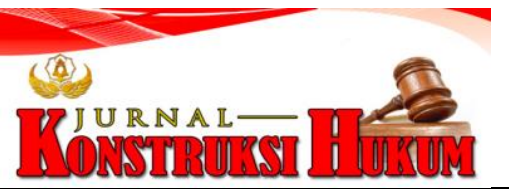

\title{
AKIBAT HUKUM TERHADAP PENGGUNAAN AIR BAWAH TANAH TANPA IZIN
}

\author{
I Gusti Agung Gede Catra Artawan, I Nyoman Budiartha, I Nyoman Sutama \\ Fakultas Hukum Universitas Warmadewa, Denpasar-Bali, Indonesia
}

\begin{abstract}
Abstrak
Air bawah tanah adalah air yang terkandung dalam lapisan tanah atau batuan di bawah permukaan tanah. Penelitian ini bertujuan untuk mengetahui wewenang pemerintah dalam mengatur izin air tanah dan apa konsekuensi hukum dari pelanggaran penggunaan air bawah tanah tanpa izin. Penelitian dilakukan dengan menggunakan metode penelitian hukum empiris, sember data menggunakan bahan hukum primer dan sekunder, metode pengumpulan bahan hukum menggunakan studi dokumentasi dan penelitian lapangan, dan menganalisis bahan hukum menggunakan metode analisis deskriptif. Hasil penelitian menunjukkan bahwa kewenangan Pemerintah dalam perizinan air tanah diatur dalam Peraturan Gubernur Bali Nomor 5 Tahun 2016 tentang Perizinan Air Tanah, khususnya dalam Pasal 3 ayat (1), dijelaskan bahwa Gubernur memiliki wewenang untuk mengelola air tanah di CAT di wilayah provinsi. Dalam Pasal 3 ayat (2), kewenangan Pemerintah (Gubernur) ditegaskan kembali, termasuk beberapa hal, yaitu: pemberian izin untuk pengeboran air tanah; memberikan izin untuk penggalian air tanah; memberikan izin untuk penggunaan air tanah; memberikan izin untuk eksploitasi air tanah; memberikan izin kepada perusahaan pengeboran air tanah; melakukan bimbingan, mengawasi investigasi teknis dan penggunaan Air Tanah. Sebagai akibat dari pelanggaran penggunaan air tanah dengan melanggar pihak sesuai dengan Pasal 15 ayat (1) Undang-Undang Nomor 11 Tahun 1974 tentang Irigasi, dinyatakan bahwa siapa pun yang dengan sengaja melakukan usaha air dan atau sumber air tanpa izin dari Pemerintah diancam dengan pidana penjara 2 (dua) tahun dan atau denda maksimal Rp. 5.000.000 (lima juta rupiah).
\end{abstract}

Kata kunci: Akibat hokum; Izin air tanah; Kewenangan

\begin{abstract}
Underground water is water that is contained in a layer of soil or rock below the soil surface. This study aims to determine the government's authority in regulating groundwater permits and what are the legal consequences of violating unlicensed groundwater use. The research was conducted using empirical legal research methods, source of the data which was used are primary and secondary sources of legal materials, methods of collecting legal materials using documentation studies and field research, and analyzing legal materials using descriptive analysis methods. The results of this study indicate that the Government's authority in permitting groundwater is regulated in the Bali Governor Regulation Number 5 of 2016 concerning Groundwater Permits, particularly in Article 3 paragraph (1), it is explained that the Governor has the authority to manage groundwater in CAT in the province. In Article 3 paragraph (2), the authority of the Government (Governor) is reaffirmed, including several things, namely: granting permits for groundwater drilling; give permission to extract groundwater; grant permits for the use of groundwater; granting permits for groundwater exploitation; grant permits to groundwater drilling companies; provide guidance, supervise technical investigations and use of Groundwater. As a result of violations of the use of groundwater by violating the parties in accordance with Article 15 paragraph (1) of Law Number 11 of 1974 concerning Irrigation, it is stated that anyone who deliberately runs water and / or water sources business without permission from the Government is punishable by imprisonment. 2 (two) years and or a maximum fine of $R p .5,000,000$ (five million rupiah).
\end{abstract}

Key words: Legal consequences; Underground water permit; Authority

\section{PENDAHULUAN}

Peran utama pemerintah dalam negara kesejahteraan adalah bagaimana mewujudkan kesejahteraan umum rakyatnya. Untuk alasan ini, pemerintah, akan menggunakan kebebasan atau kemerdekaan ini untuk berpartisipasi dalam kegiatan sosial, politik dan ekonomi untuk mewujudkan kesejahteraan masyarakat. Undang- undang perizinan bertujuan untuk mewujudkan kesejahteraan masyarakat, yang keberadaannya bermanfaat dan tidak menimbulkan bahaya bagi kehidupan. Jika ada penyimpangan 
dalam kegiatan, mereka akan terdeteksi oleh publik dalam mekanisme kontrol yang dilembagakan dan tersedia (Harun, 2012). Salah satunya terkait dengan penggunaan izin air bawah tanah.

Air bawah tanah adalah air yang terkandung dalam lapisan bawah tanah atau pada batuan di bawah permukaan tanah. Air bawah tanah memiliki peran penting sebagai salah satu sumber mata air yang digunakan untuk memenuhi kebutuhan air masyarakat. Utamanya adalah untuk memenuhi kebutuhan pokok akan air pada kehidupan sehari-hari, selain juga digunakan untuk keperluan lainnya. Salah satu fungsi atau peran air bawah tanah adalah untuk keperluan usaha. Tetapi berbeda dengan dalam penggunaan pemenuhan kebutuhan sehari-hari yang tidak harus memiliki izin, tetapi apabila digunakan untuk usaha harusnya mencari izin penggunaan dengan mengikuti prosedur yang dijalankan (Wahyono \& Wardiat, 2012).

Prosedur dalam mencari izin penggunaan air tanah telah diatur dalam peraturan yang berlaku. Tidak hanya itu saja, apabila izin telah dikeluarkan, maka dipemegang atau pemilik izin harus harus mengindahkan atas izin yang dimiliki. Apabila pemilik izin melakukan pelanggaran dengan berbagai kegiatan yang dapat melebihi batas ketentuan penggunaan air tanah sehingga menyebabkan kerusakan ekosistem alamiah maka dapat dikenakan sanksi hukum seperti yang diatur dalam peraturan perundang-undangan (Nagara, 2009). Tidak ada yang berjalan dengan teratur apabila tidak ada kesadaran dari pemegang izin akan aturan yang ada.

Terakit dengan peraturan yang mengatur tentang air tanah salah satunya adalah UndangUndang Nomor 7 Tahun 2002 tentang Sumber Daya Air yang dimana pada Pasal 9 ayat (1) disebutkan: "Hak guna usaha air dapat diberikan kepada perseorangan atau badan usaha dengan izin dari Pemerintah atau pemerintah daerah sesuai dengan kewenangannya". Ini menyiratkan bahwa untuk menggunakan air bawah tanah dalam jumlah besar perlu untuk mengurus izin. Hal ini dimaksudkan untuk mencegah eksploitasi penggunaan air bawah tanah, mengingat bahwa di tengah perkembangan dunia bisnis, semakin tinggi tingkat penggunaan air bawah tanah juga terjadi. Pelanggaran atas hak izin penggunaan air ini tidak selanyaknya terus dilakukan karena sebenarnya telah diatur dan ditetapkan sanksi hukumnya dalam peraturan perundang-undangan. Pasal Peraturan Gubernur Bali Nomor 5 Tahun 2016 tentang Perizinan Air Bawah Tanah, pada Pasal 10 dijelaskan bahwa: "Pengusahaan air bawah tanah dilakukan setelah memiliki Izin Pengusahaan Air Bawah Tanah". Selanjutnya, Pasal 10 juga menjelaskan bahwa eksploitasi air bawah tanah adalah kegiatan menggunakan air bawah tanah untuk bisnis yang bertujuan memenuhi kebutuhan seperti bahan baku untuk produksi; potensi pemanfaatan; media bisnis; atau bahan pendukung atau proses produksi.

Beberapa dekade terakhir ini ternyata masih banyak terjadi kasus penyalahgunaan penggunaan air bawah tanah baik yang legal maupun illegal (Widowati \& Ikasari, 2011). Hal ini dapat dilihat atas banyaknya berita, baik itu di surat kabar, media sosial maupun di media elektronik. Keadaan ini akan sangat memengaruhi fungsi air bawah tanah.

Meskipun ada aturan yang jelas mengenai penggunaan air bawah tanah, pelanggaran penggunaannya masih terjadi, salah satunya terkait dengan pengelolaan izin penggunaan air tanah. Berdasarkan uraian di atas, penelitian ini bertujuan untuk mengetahui kewenangan pemerintah dalam pemberian izin air bawah tanah dan bagaimana akibat hukum atas pelanggaran penggunaan air bawah tanah tanpa izin.

\section{METODE PENELITIAN}

Penelitian ini menggunakan metode penelitian dengan empiris. Pendekatan untuk menyelesaikan masalah dalam penelitian ini adalah pendekatan perundang-undangan, konsep dan fakta. Bahan hukum primer dan bahan hukum sekunder menjadi bahan hukum yang digunakan dalam menyelesaikan fenomena dalam masalah formulasi. Pengumpulan materi hukum dilakukan dengan menggunakan metode studi dokumen dan studi lapangan. Analisis bahan hukum diperoleh dan dikumpulkan dengan menganalisis interpretasi dan kemudian disajikan deskriptif analitis.

\section{HASIL DAN PEMBAHASAN}

\section{Kewenangan Pemerintah dalam Pemberian Izin Air Bawah Tanah}

Peran air bawah tanah yang begitu penting dalam kehidupan sehari-hari menjadikannya mendapatkan perhatian khusus bagi pemerintah. Air bawah tanah pada dasarnya diutamakan untuk memenuhi kebutuhan masyarakat sehari-hari terlebih dahulu sebelum digunakan untuk keperluan lainnya seperti untuk aktivitas usaha. Keberadaan air bawah tanah ini pada dasarnya memang melimpah ruah 
dan tak terbatas, tetapi dengan seiring perkembangan jaman maka ketersediaan air bawah tanah makin disalah gunakan, terutama dalam penggunaannya untuk keperluan usaha.

Penggunaan air tanah untuk aktivitas usaha memanglah harus memenuhi kriteria yang ditetapkan dalam peraturan perundang-undangan. Selain itu untuk penggunaan air bawah tanah untuk usaha juga harus memiliki izin usaha. Di dalam peraturan dijelaskan bahwa pemegang izin juga memiliki kewajiban yang harus dipenuhi, termasuk didalamnya yaitu tidak diizinkan untuk menggunakan melebihi ketentuan penggunaan air tanah untuk kepentingan usahanya. Penggunaan air tanah tersebut haruslah bijak tanpa menyebabkan terjadinya kerusakan lingkungan.

Dalam Pasal 6 Peraturan Gubernur Bali No. 5 Tahun 2016 tentang Perizinan Air bawah tanah dijelaskan bahwa: "Penyediaan air tanah untuk penatagunaan, penyediaan, penggunaan, pengembangan, dan pengusahaan bertujuan untuk memenuhi kebutuhan air dari pemanfaatan air tanah untuk berbagai keperluan sesuai dengan kualitas dan kuantitasnya. Penyediaan air tanah pada CAT dalam daerah provinsi dilaksanakan sesuai dengan urutan prioritas, yakni kebutuhan pokok sehari-hari, pertanian rakyat, sanitasi lingkungan, pariwisata, industry, dan kepentingan lainnya."

Dalam Pasal 9 Peraturan Gubernur Bali No. 5 Tahun 2016 tentang Perizinan Air Tanah, dinyatakan bahwa hak untuk menggunakan air dari pemanfaatan air tanah diperoleh tanpa izin jika itu untuk memenuhi kebutuhan dasar harian individu dan pertanian skala kecil. Hak untuk menggunakan air dari penggunaan air tanah untuk memenuhi kebutuhan dasar harian bagi individu ditentukan, meliputi: penggunaan air tanah dari lubang bor dengan diameter tidak lebih dari 4 (dua) inci, penggunaan air tanah menggunakan tenaga manusia dari sumur gali, atau penggunaan air tanah kurang dari $100 \mathrm{~m} 3$ / bulan per rumah tangga tanpa menggunakan sistem distribusi terpusat.

Hak untuk menggunakan air dari penggunaan air tanah untuk memenuhi kebutuhan pertanian masyarakat ditentukan sebagai berikut: sumur ditempatkan di daerah pertanian yang jauh dari pemukiman; penggunaan tidak lebih dari 2 (dua) liter per detik per kepala rumah tangga jika air permukaan tidak mencukupi; dan Debit air tanah tidak mengganggu kebutuhan dasar sehari-hari masyarakat setempat terakit dengan prosedur dan persyaratan untuk mengajukan izin baik itu pengeboran/penggalian, penggunaan ataupun pemanfaatan air bawah tanah diatur dalam Pasal 14 Peraturan Gubernur Bali Nomor 5 Tahun 2016 tentang Perizinan Air Bawah Tanah.

Dalam Pasal 3 ayat (1) dijelaskan bahwa Gubernur memiliki wewenang untuk mengelola air tanah pada CAT di wilayah provinsi. Dalam Pasal 3 ayat (2), ditegaskan kembali bahwa kewenangan Pemerintah (Gubernur) mencakup beberapa hal, diantaranya: memberikan Izin Pengeboran Air Tanah; memberikan izin Penggalian Air Tanah; memberikan Izin Pemakaian Air Tanah; memberikan izin Pengusahaan Air Tanah; memberikan Izin Perusahaan Pengeboran Air Tanah; melakukan pembinaan, pengawasan teknis penyelidikan dan pemanfaatan Air Tanah.

Penetapan izin penggunaan air bawah tanah itu perlu mengingat terjadinya beberapa kasus penyalahgunaan air bawah tanah untuk keperluan usaha, dimana pemilik usaha yang memanfaatkan air bawah tanah menggunakannya melebihi dari kapasitasnya (Rejekiningrum, 2009; Widowati \& Ikasari, 2011). Untuk alasan ini, sebagaimana dijelaskan dalam Pasal 3 ayat (2) di atas, pemerintah harus lebih berhati-hati dalam mengeluarkan izin untuk penggunaan air bawah tanah. Selain itu, dalam melaksanakan wewenangnya, hal itu sebenarnya diterapkan pada poin keenam, yaitu untuk memberikan panduan, menyelidiki pengawasan teknis dan penggunaan Air Tanah.

Pembinaan dalam penggunaan air tanah diadakan dalam bentuk arahan, bimbingan, bimbingan, dan konseling. Kegiatan pengembangan air tanah dilakukan oleh Dinas terkait secara berkala. Pengendalian penggunaan air tanah sebagaimana dimaksud dalam CAT di wilayah provinsi dilakukan pada bagian CAT yang mengambil air tanah intensif; Melepaskan area air tanah; dan / atau akuifer air tanah yang sangat dieksploitasi. Kegiatan pengendalian air tanah dilakukan oleh Dinas terkait secara berkala. Supervisi pengeboran, penggalian, penggunaan, dan eksploitasi air tanah berdasarkan ketentuan yang tercantum dalam Rekomendasi Teknis dan Izin.

Hak guna usaha air dapat diberikan kepada perseorangan atau badan usaha dengan izin dari Pemerintah atau pemerintah daerah sesuai dengan kewenangannya (Al Rosyid Noor \& Khunaefi, 2019; Azil Maskur, 2019). Ini menyiratkan bahwa untuk menggunakan air bawah tanah dalam jumlah besar perlu untuk mengurus izin. Hal ini dimaksudkan untuk mencegah eksploitasi penggunaan air bawah tanah, mengingat bahwa di tengah perkembangan dunia bisnis, semakin tinggi 
tingkat penggunaan air bawah tanah juga terjadi. Apabila pemiliki izin melanggar kewajiban maka dapat dikenai sanksi hukum seperti yang telah diamanatkan dalam peraturan perundang-undangan yang berlaku baik itu peraturan pusat maupun peraturan daerah.

Dalam Peraturan Gubernur Bali Nomor 5 Tahun 2016 tentang Perizinan Air Bawah Tanah, pada Pasal 10 dijelaskan bahwa: "Pengusahaan air bawah tanah dilakukan setelah memiliki Izin Pengusahaan Air Bawah Tanah". Penggunaan air tanah yang berlebihan tanpa memperhatikan lingkungan maka akan menyebabkan kerusakan lingkungan dan ekosistem lingkungan. Oleh karena itu, penggunaan air tanah untuk keperluan di luar keperluan utamanya untuk memenuhi kebutuhan masyarakat, maka harus memperhatikan pola pengelolaan air bawah tanah yang sedikit tidaknya harus terintegrasi dan memperhatikan keseimbangan ekosistem alami air dan lingkungan. Berbagai upaya telah dilakukan oleh pemerintah melalui dengan menetapkan sanksi atas penyalahgunaan air bawah tanah hingga beberapa peraturan lainnya untuk menjaga keseimbangan pola ekosistem alamiah. Tetapi meskipun demikian, masih terdapat pelanggaran atas kasus penggunaan air bawah tanah yang berlebih dan tidak mengindahkan peraturan yang berlaku.

Keberadaan kasus ini menunjukkan bahwa tingginya tingkat penyalahgunaan air bawah tanah terjadi di masyarakat. Ini dipengaruhi oleh beberapa faktor baik internal maupun eksternal masyarakat. Pada dasarnya, prosedur dan persyaratan untuk mendapatkan izin penggunaan tidak sulit, tetapi yang terjadi justru sebaliknya. Dalam Pasal 16 Peraturan Gubernur Bali No. 5 Tahun 2016 tentang Izin Air Bawah Tanah, dinyatakan bahwa kewajiban pemegang izin adalah Setiap pemegang izin agar melaksanakan ketentuan-ketentuan yang tertuang dalam rekomendasi teknis dan perizinan. Kemudian, setiap pemegang izin agar melakukan tindakan-tindakan konservasi air tanah berupa pembuatan Lubang Resapan dan Sumur Resapan untuk meresapkan air hujan. Selanjutnya, setiap pemegang izin agar membuat 1 (satu) unit sumur pantau pada pengambilan air tanah melalui 5 (lima) atau lebih unit sumur produksi pada area kurang dari 1 (satu) hektar atau pengambilan air tanah minimal debit (empat) lt/dt yang berasal dari 1 (satu) unit sumur produksi. Yang terakhir, setiap pemegang izin agar memasang meter air yang sudah dikalibrasikan pada instansi yang berwenang dan menggantinya apabila terjadi kerusakan.

Jika pemegang izin tidak dapat memenuhi kewajibannya, izin penggunaan air tanah dapat dicabut (Pasal 17 ayat (1) huruf c). Pencabutan dilakukan setelah diberikan peringatan tertulis kepada pemegang izin yang bersangkutan 3 (tiga) kali berturut-turut dengan masa tenggang 1 (satu) bulan. Pencabutan izin tidak membebaskan kewajiban keuangan dan kewajiban lain yang ditetapkan oleh pemerintah daerah.

\section{Akibat Hukum terhadap Penggunaan Air Bawah Tanah tanpa Izin}

Hukum adalah sarana yang mengandung nilai atau konsep tentang keadilan, kebenaran, kemanfaatan, sosial, dan sebagainya (Budiardjo, 1982). Penegakan hukum adalah upaya untuk mengindahkan hukum diatas peraturan yang telah ditetapkan dalam perundang-undangan (Rahardjo, 1996). Selain itu penegakan hukum juga dapat diinterpretasikan sebagai suatu pandangan akan penegakan nilai-nilai hukum yang ada di masyarakat demi menciptakan kesejahteraan sosial kehidupan (Soekanto, 1983).

Undang-undang Nomor 7 Tahun 2004 tentang Sumber Daya Air pada Pasal 3 yang juga menjadi tujuan pengelolaan sumber daya air mengamanatkan "sumber daya air dikelola secara menyeluruh, terpadu dan berwawasan lingkungan dengan tujuan mewujudkan kemanfaatan sumber daya air yang berkelanjutan untuk kemakmuran rakyat".

Berdasarkan aturan ini, sumber daya air yang perlu dikelola dengan baik akan dapat meningkatkan kesejahteraan masyarakat, dan kebutuhan masyarakat akan kebutuhan udara harian dapat mendukung. Peraturan Gubernur Bali Nomor 5 Tahun 2016 tentang Perizinan Air Tanah tentang hak untuk menggunakan air dari tanah yang diperoleh tanpa izin untuk kebutuhan sehari-hari bagi individu dan pertanian skala kecil. Hak untuk menggunakan air dari penggunaan lahan untuk memenuhi kebutuhan sehari- hari individu yang bertekad untuk menggunakan lahan dari lubang bor dengan diameter maksimum 4 (dua) inci; penggunaan air tanah menggunakan tenaga manusia dari sumur gali; atau menggunakan air tanah kurang dari $100 \mathrm{~m} 3 /$ bulan per rumah tangga tanpa menggunakan sistem distribusi terpusat.

Berdasarkan Peraturan Daerah Nomor 6 Tahun 2014 tentang Pengelolaan Air Tanah tepatnya Pasal 22 disebutkan bahwa urutan prioritas peruntukan pemanfaatan air tanah adalah 
sebagai berikut: Air minum, Air untuk rumah tangga, Air untuk peternakan dan pertanian rakyat, Air untuk irigasi, Air untuk industry, Air untuk pertambangan, Air untuk usaha perdagangan, Air untuk kepentingan lainnya.

Akibat terhadap pelanggaran pemanfaatan air bawah tanah yang dilakukan para pihak yang melanggar menurut Pasal 15 ayat (1) Undang-Undang Nomor 11 Tahun 1974 tentang Pengairan, disebutkan bahwa: "Diancam dengan hukuman penjara selama-lamanya 2 (dua) tahun dan atau denda setinggi-tingginya Rp 5.000.000,- (lima juta rupiah): siapa pun yang dengan sengaja melakukan bisnis pada sumber air dan atau air yang tidak didasarkan pada perencanaan dan perencanaan teknis pengaturan air dan irigasi dan pengembangan irigasi; siapa pun yang dengan sengaja mengusahakan air dan atau sumber air tanpa izin dari Pemerintah; barang siapa yang sudah memperoleh izin dari Pemerintah untuk pengusahaan air dan atau sumber air sebagaimana tersebut dalam Pasal 11 ayat (2) Undang-undang ini, tetapi dengan sengaja tidak melakukan dan atau sengaja tidak ikut membantu dalam usaha menyelamatkan tanah, air, sumber air dan bangunan-bangunan pengairan sebagaimana tersebut dalam Pasal 13 ayat (1) huruf a, b, c, dan d Undang-undang ini. Hal yang menyebabkan penggunaan air bawah tanah tanpa izin adalah kurangnya kesadaran pemilik usaha, kemudian terkendala pada prosedur yang belaku, dan tidak mengindahkan peraturan yang ada.

\section{SIMPULAN DAN SARAN}

\section{Simpulan}

Simpulan dari hasil penelitian, meliputi kewenangan Pemerintah dalam perizinan air tanah di atur dalam Peraturan Gubernur Bali Nomor 5 Tahun 2016 tentang Perizinan Air Bawah Tanah, khususnya pada Pasal 3 ayat (1) dijelaskan bahwa Gubernur memiliki wewenang pengelolaan air tanah pada CAT dalam daerah provinsi. Dalam Pasal 3 ayat (2) kembali dipertegas adapun kewenangan Pemerintah (Gubernur) mencakup beberapa hal yaitu: memberikan Izin Pengeboran Air Tanah; memberikan izin Penggalian Air Tanah; memberikan Izin Pemakaian Air Tanah; memberikan izin Pengusahaan Air Tanah; memberikan Izin Perusahaan Pengeboran Air Tanah; melakukan pembinaan, pengawasan teknis penyelidikan dan pemanfaatan Air Tanah. Selanjutnya, akibat terhadap pelanggaran pemanfaatan air bawah tanah yang dilakukan para pihak yang melanggar menurut Pasal 15 ayat (1) Undang-Undang Nomor 11 Tahun 1974 Tentang Pengairan, disebutkan bahwa siapa pun yang dengan sengaja melakukan bisnis pada sumber air dan / atau air tanpa izin dari Pemerintah terancam hukuman penjara hingga 2 (dua) tahun dan atau denda maksimum Rp 5.000.000 (lima juta rupiah).

\section{Saran}

Beberapa saran penelitian berdasarkan penelitian ini, yakni bagi Pemerintah agar meninjau kembali Peraturan Gubernur Bali No. 5 tahun 2016 tentang Perizinan Air Tanah, khususnya mengenai sanksi atas pelanggaran penggunaan air tanah tanpa izin, sehingga mereka yang menggunakan air di luar masyarakat dan petani (atau untuk pengusaha) menjadi lebih sadar. tentang pentingnya mengurus izin dan menggunakan izin yang mereka miliki sebaik mungkin. Kemudian, bagi pemerintah bidang perizinan untuk melakukan berbagai kegiatan yang dapat meningkatkan kesadaran masyarakat dan pengusaha dalam menggunakan air bawah tanah seperti dengan melakukan sosialisasi atau dengan memasang reklame, untuk contoh berupa spanduk atau poster dan pengawasan penggunaan air bawah tanah sehingga mengurangi terjadinya pelanggaran penggunaan air bawah tanah tanpa izin.

\section{DAFTAR PUSTAKA}

Al Rosyid Noor, A., \& Khunaefi, A. (2019). Konsep Pengelolaan Sumber Daya Air Pasca Putusan Mahkamah Konstitusi Nomor 85/PUU-XI/2013. Notaire, 2(1), 1-18.

Azil Maskur, M. (2019). Kebijakan Pengelolaan Air Pasca Putusan Mahkamah Konstitusi tentang Undang-Undang Sumber Daya Air. Jurnal Konstitusi, 16(3), 510-531.

Budiardjo, M. (1982). Dasar-Dasar Ilmu Politik. Gramedia.

Harun. (2012). Prospective Industrial Business Licensing Construction. Fakultas Hukum Muhammadiyah University.

Nagara, G. (2009). Perkembangan Sanksi Administratif dalam Penguatan Perlindungan lingkungan terkait Eksploitasi Sumber Daya Alam (Studi Kasus : Sektor Perkebunan, Pertambangan, dan 
Kehutanan). Jurnal Lingkungan Hukum, 3(2), 19-44.

Rahardjo, S. B. (1996). Law Enforcement Problems A Sociological Review. Sinar Baru.

Rejekiningrum, P. (2009). Peluang Pemanfaatan Air Tanah untuk Keberlanjutan Sumber Daya Air. Jurnal Sumberdaya Lahan, 3(2), 85-96.

Soekanto, S. (1983). Penegak Hukum. Binacipta.

Wahyono, A., \& Wardiat, D. (2012). Integritas Pelayanan Publik Dalam Perizinan Pemanfaatan Air BAwah Tanah di DKI Jakarta. Masyarakat Dan Budaya, 14(10), 99-126.

Widowati, D. A., \& Ikasari, I. H. (2011). Peranan Pajak Pemanfaatan dan Pengambilan Air Bawah Tanah terhadap Konservasi Air Tanah. Mimbar Hukum, 23(2), 307-327. 